\title{
Evaluation of the European Union-United States oil and petroleum-based fuels trade potential in the context of the negotiated TTIP agreement
}

\author{
Tadeusz Olkuski ${ }^{1,}{ }^{*}$, Andrzej Pawet Sikora ${ }^{2}$, Mateusz Piotr Sikora ${ }^{3}$, Adam Szurlej ${ }^{4}$ \\ ${ }^{1}$ AGH University of Science and Technology, the Faculty of Energy and Fuels, Poland \\ ${ }^{2}$ The Energy Studies Institute in Warsaw, Poland \\ ${ }^{3}$ The Energy Studies Institute in Warsaw, Poland \\ ${ }^{4}$ AGH University of Science and Technology, the Faculty of Drilling, Oil and Gas, Poland
}

\begin{abstract}
The article evaluates the European Union-United States oil and petroleum-based fuels trade potential. The planned trade structure and balance according to IEA (International Energy Agency) and IHS (IHS CERA www.ihs.com)) scenarios, the projected volume of imports and exports, and differences in price levels and costs are presented. The projected potential of the trade volume, taking into account the possible impact of the Transatlantic Trade and Investment Partnership (TTIP), is also presented. The analysis has shown that the elimination of trade barriers between the European Union and the United States would be more beneficial to US refineries. Due to the higher import tariffs to the EU, the potential benefits of US exporters are higher than those of the EU exporters to the US. This confirms the fears of European negotiators that some aspects of the agreement will have a negative impact on European businesses. However, in the case of petroleum products the TTIP agreement will have a negligible impact on increasing the export volume.
\end{abstract}

\section{Introduction}

The chemical composition of oil is variable depending on extraction site. There is a whole range of types of crude oil, while the most common classification of oils is based on two dimensions [1]:

- The density determining the proportions between light (more valuable) and heavy (less valuable) hydrocarbons in crude oil, measured by the API gravity. API Gravity is a specific scale developed by the American Petroleum Institute (API) for measuring the density of different types of oil:

- Light crude oil - API higher than $33^{\circ}$,

$\circ$ Medium oil - API between $22^{\circ}$ and $33^{\circ}$,

○ Heavy oil - API below $22^{\circ}$.

- Sulphur content of crude oil:

\footnotetext{
* Corresponding author: olkuski@agh.edu.pl
} 
- Sweet crude oil - less than $0.5 \%$ sulphur,

- Medium sour crude oil - between 0.5 and $2.0 \%$ sulphur

- Sour crude oil - more than $2.0 \%$ sulfur.

In addition, the proportions of individual hydrocarbon groups in a given crude oil (paraffins, aromatics, and naphthenes), the shape of the distillation curve, vapor pressures, viscosities, pour points, the hydrogen sulfide, heavy metal, acidic compounds, chlorides and salt contents are all of a great importance. Conversion of almost every lighter and sweeter oil to heavier and sourer (sulfated) oil is technically possible. However, this raises the question whether such conversions are economically justified. The possibility of conversion in the opposite direction is limited due to the structure and processing capacities of refineries As a consequence, the mentioned relationships have to be taken into account when analyzing the potential oil trade between the United States and the European Union. An analysis of refinery products is easier, because these products (quality standards) are now very similar, while minimum differences should not have a significant impact on the potential oil trade. For example, the permissible sulfur content in diesel fuel in the United States and in the EU is 15 and $10 \mathrm{ppm}$, respectively.

\section{The structure of the planned oil trade}

The comparison of oil trade between the United States and the European Union (excluding Canadian and Norwegian deposits) shows that both areas remain importers of this raw material. It is worth noting that the level of dependence on external supplies of oil in the US is 2.5 times lower than in the EU (Fig. 1). When taking into account the production from Canadian and Norwegian deposits (Fig. 2) the situation of the EU slightly improves, while the economic situation of the United States changes dramatically. Canadian oil, along with unconventional deposits, can be potentially exported. The conditions prevailing in North America, favorable when compared to the EU conditions, result from, among others, the socalled shale revolution. It can be assumed that the shale oil revolution started in 2008, three years later than shale gas revolution [2].

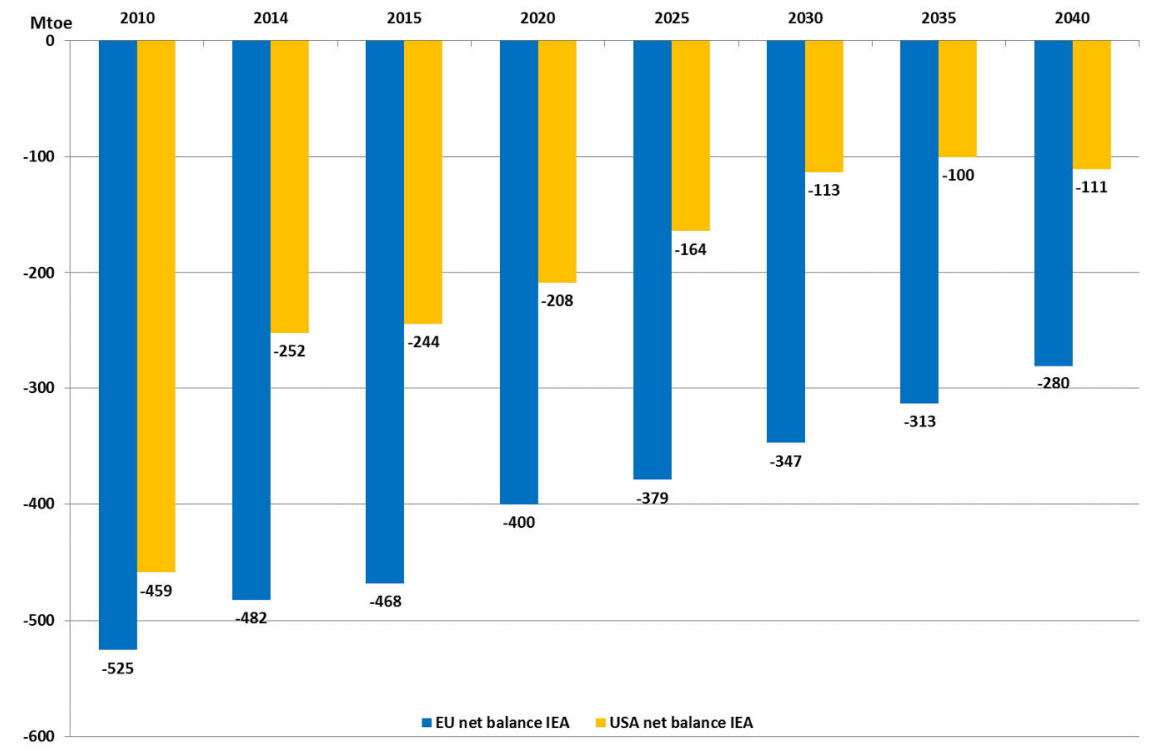

Fig. 1. The net trade balance of oil in the United States and European Union countries in the IEA baseline scenario - excluding Canadian and Norwegian deposits [3] 


\section{Energy and Fuels 2016}

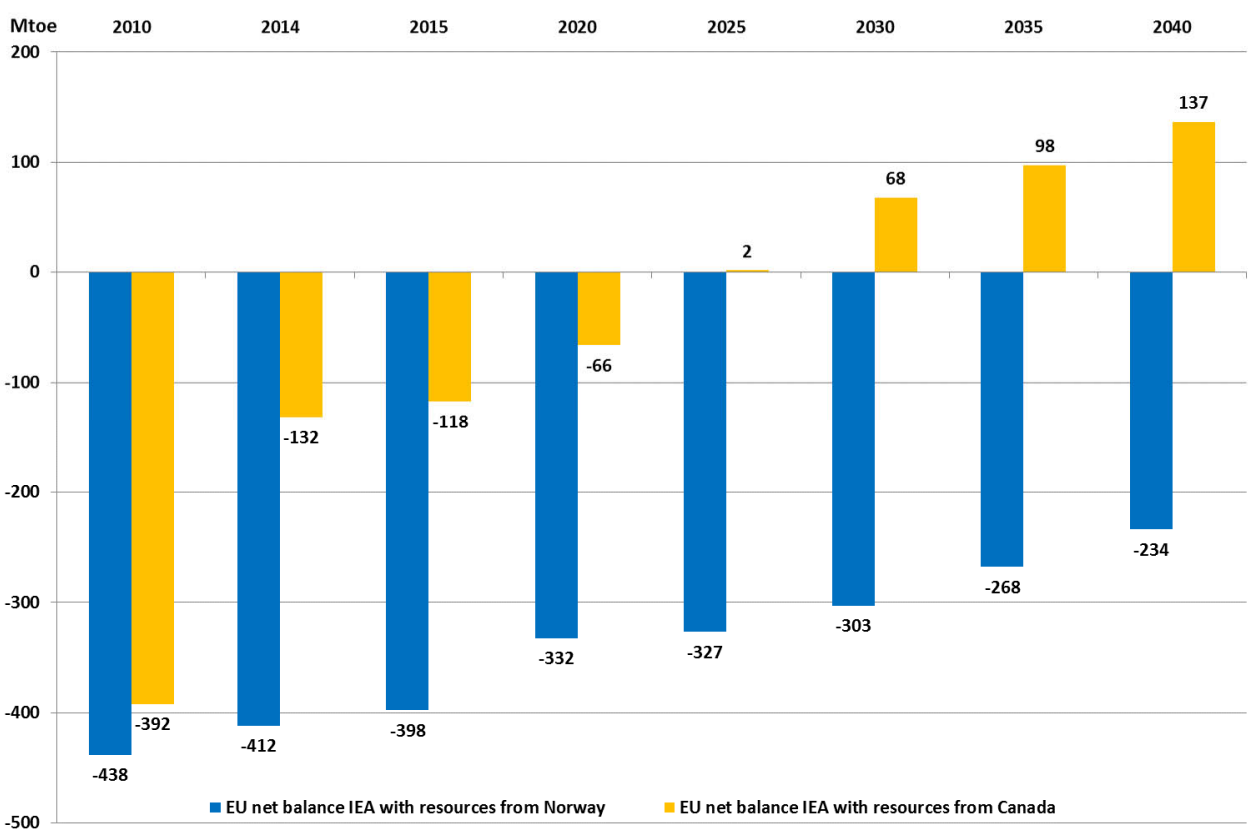

Fig. 2. The net trade balance of oil in the United States and the European Union according to the IEA baseline scenario - including Canadian and Norwegian deposits [3]

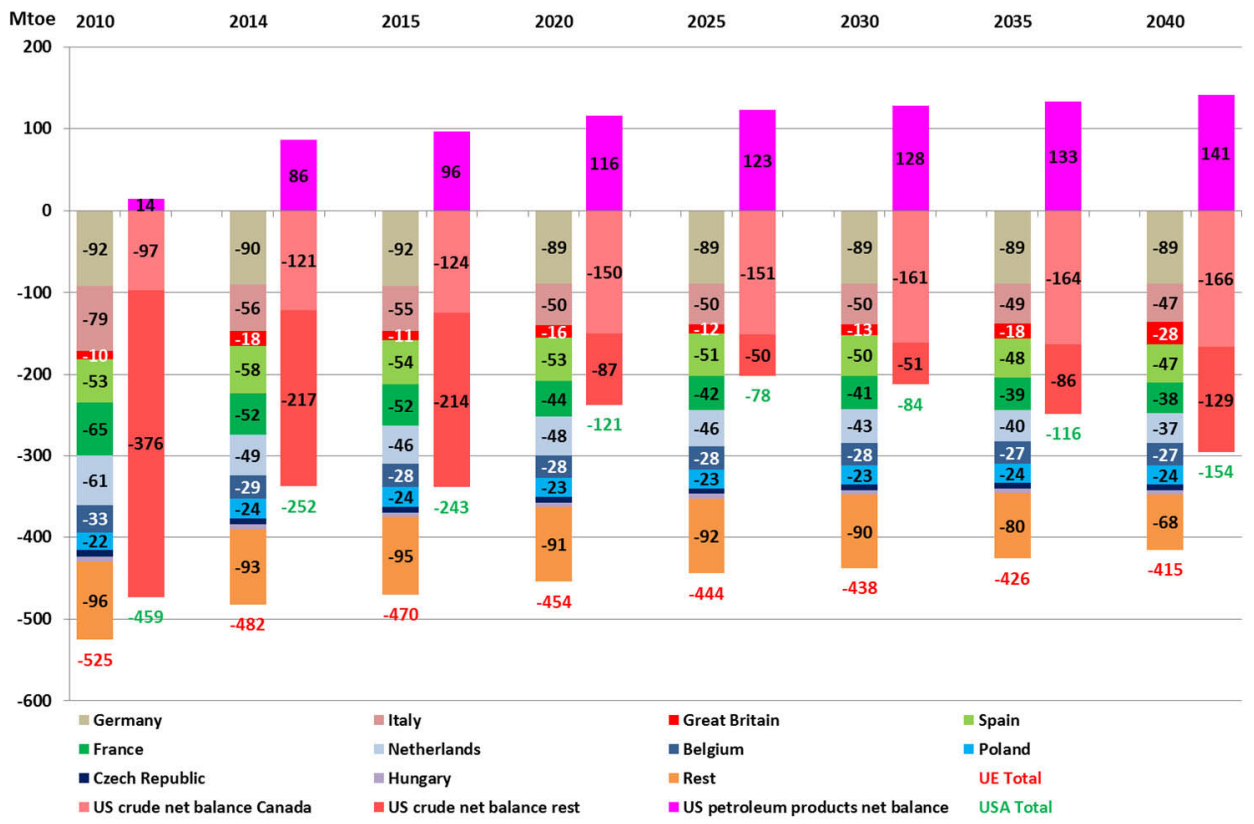

Fig. 3. The net trade balance of oil in the United States and European Union countries according to the available data compiled by the Energy Studies Institute in Warsaw [3]

The analysis carried out by the Energy Studies Institute in Warsaw, based on available market reports, has shown a similar trend (Fig. 3). Using the methodology of the International Energy Agency (IEA) [4], it is possible to take into account NGL (Natural Gas Liquids - ethane LPG, sometimes natural gasoline from natural gas deposits) and the net trade balance of 
petroleum products in addition to crude oil when estimating the oil trade on the basis of data compiled by the Energy Studies Institute in Warsaw. Experts from around the world are optimistic about the production increase in the United States, which in turn will lead to a surplus of products for export. The EU's dependence on imports decreases much more slowly than in the IEA forecast, while in the case of Germany, Italy, Belgium, and Poland, oil imports are not decreasing at all.

When analyzing the Energy Studies Institute in Warsaw data on the volume of imports and exports of oil between the United States and the European Union (Fig. 4), the increasing position of the United States in oil exports (the United States still import substantial quantities of oil) can be observed.

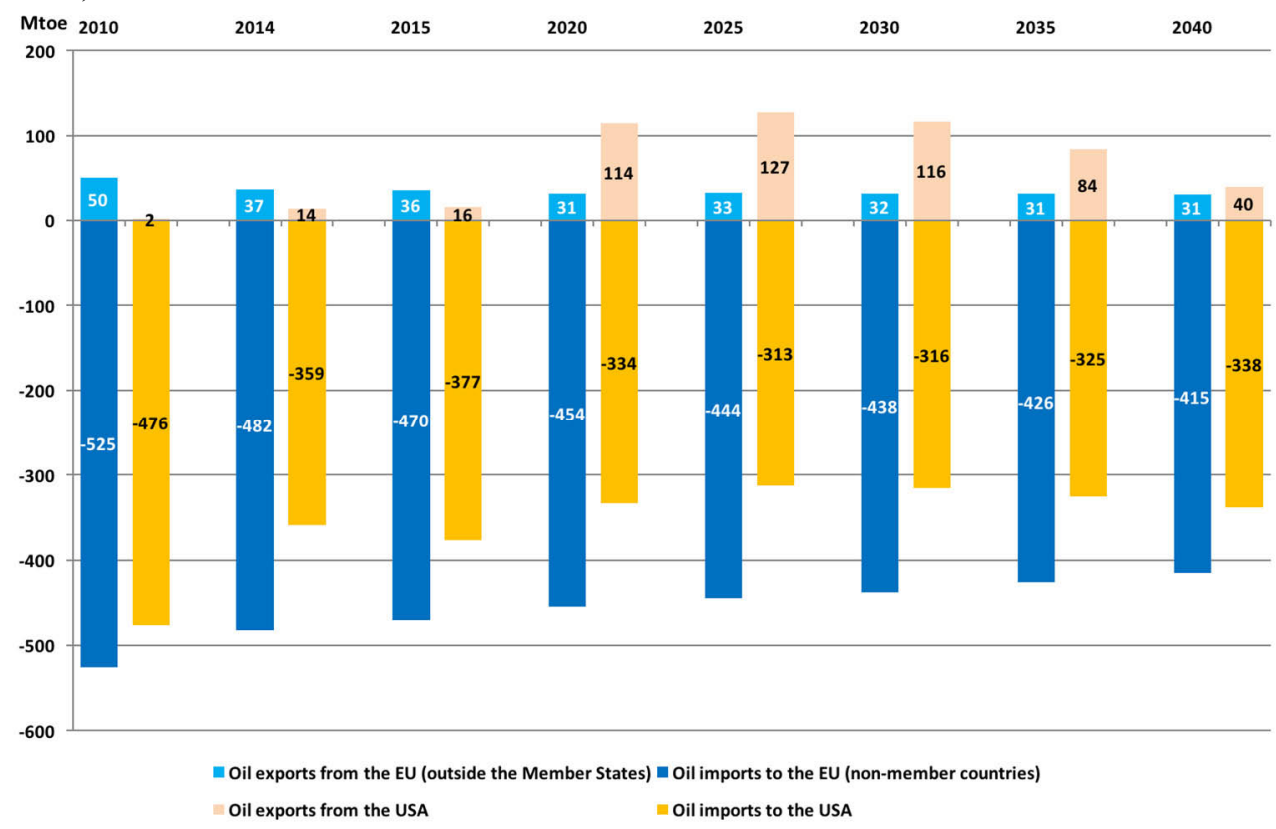

Fig.4. The forecasted volume of imports and exports of oil between the United States and the European Union on the basis of data compiled by the Energy Studies Institute in Warsaw [3]

In the recent past, the European Union (including Norway) has exported small (compared to the volumes shipped to the US from other countries) amounts of oil to the USA. However, according to the presented plans, the United States could begin to supply oil to the European Union already in 2017. On the basis of the available data, the Energy Studies Institute in Warsaw predicts initially low amounts in the range between 15-17 Mtoe/year (Fig. 5), which corresponds to the demand of the PKN Orlen refinery in Plock. Even if the TTIP agreement will fail to go beyond the stage of negotiations, and the US law will not lift the ban on imports, the obtained results have shown the economic viability of the discussed oil supplies. 


\section{Energy and Fuels 2016}

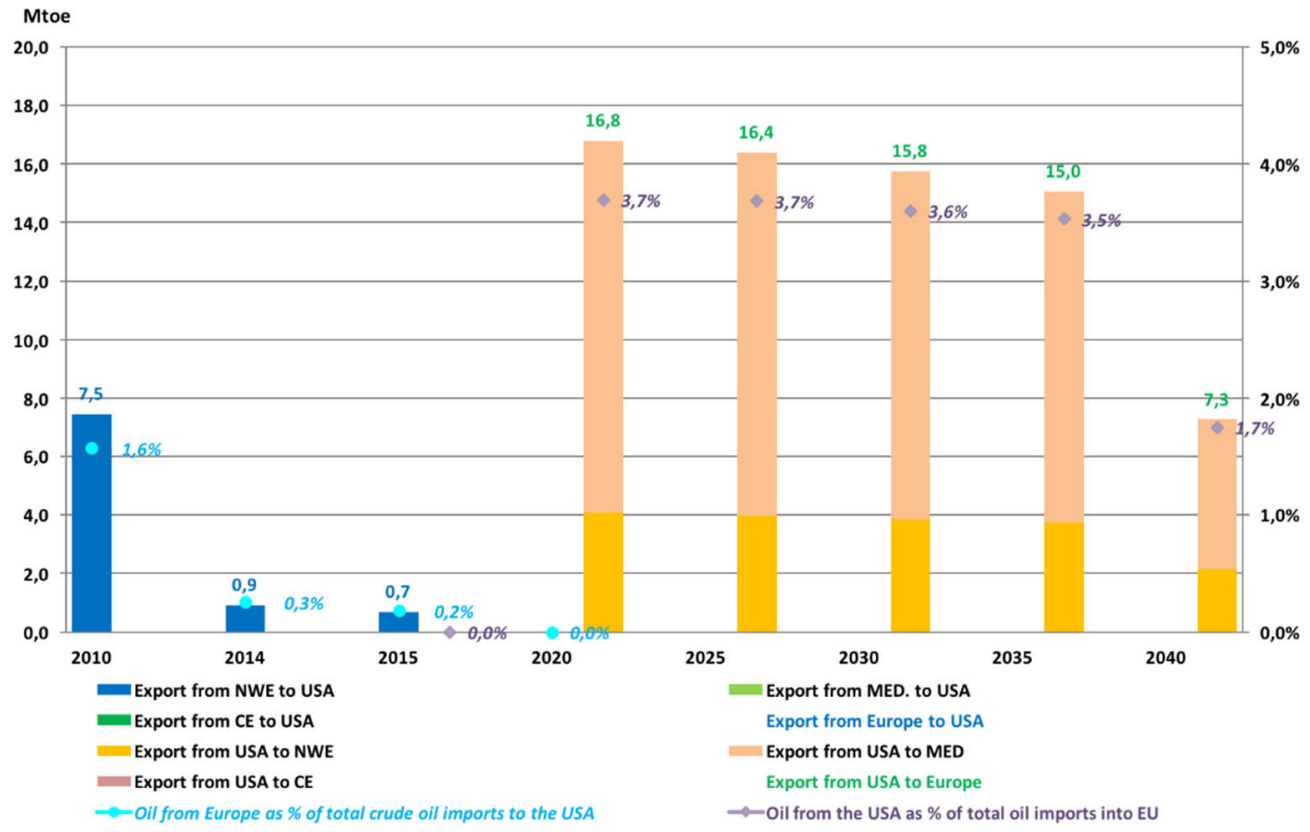

NWE - North-West Europe (The North Sea and Scandinavia)

MED - Southern Europe (the Mediterranean Basin)

$\mathrm{CE}-$ Central Europe (including Poland)

Fig. 5. The forecasted oil trade volume between the United States and the European Union (including Norway) according to the Energy Studies Institute in Warsaw (based on the available data) [3]

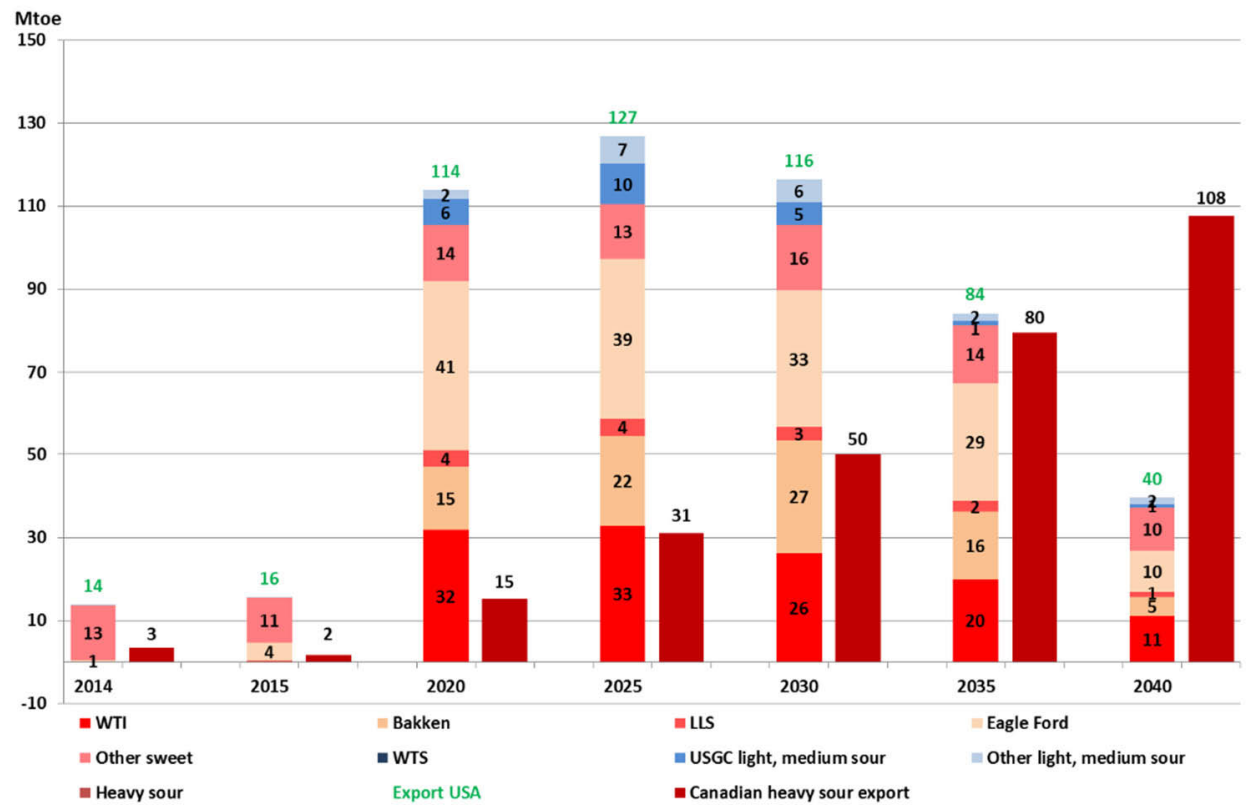

Fig. 6. The structure of the forecasted exports of crude oil from the United States and Canada broken down by oil types [3] 
An analysis of the structure of the forecasted exports of crude oil from the United States has shown that $90-100 \%$ of the exported raw material can be classified as light and sweet crude oils (WTI, LLS) or very light and sweet (tight oil) (Bakken and Eagle Ford Shale). In this case, the export of heavy crude oils (e.g. Mars Blend), or even medium-heavy and sour crude oils, is not taken into account. Instead, the structure of the forecasted exports of crude oil takes into account Canadian heavy and sour crude oil from oil shale, while sour crude oils (light and medium), e.g. Bayou Choctaw Sour and Mississippi Sour enter the market from 2020 on (10-16 Mtoe) (Fig. 6).

Crude oil imports to the European Union amount to 250-280 Mtoe/year. This is mainly due to the dominant demand for middle distillates in the structure of yields, while the most economical way to obtain them is based on converting medium sour crude oils. Sour, medium and light crude oils are among main types of the imported crude oils. They account for about $60-65 \%$ of total imports and are imported from former members of the Commonwealth of Independent States (CIS) - mainly Russia (Urals) and Kazakhstan (CPC blend) and the Persian Gulf (Arab Light, Iran Light, Iran Heavy, Kirkuk). Light crude oil accounts for about 130-150 Mtoe/year and is usually imported from Africa (Libya, Algeria, Nigeria, and Angola) and the Caspian region (BTC blend, Azeri Light) Heavy oils, with API gravity below $22-23^{\circ}$ are not refined in European petrochemical plants. This means that light and sweet crude oils from the United States and sour crude oil from Canada could form part of the imports to the EU (Fig. 7).

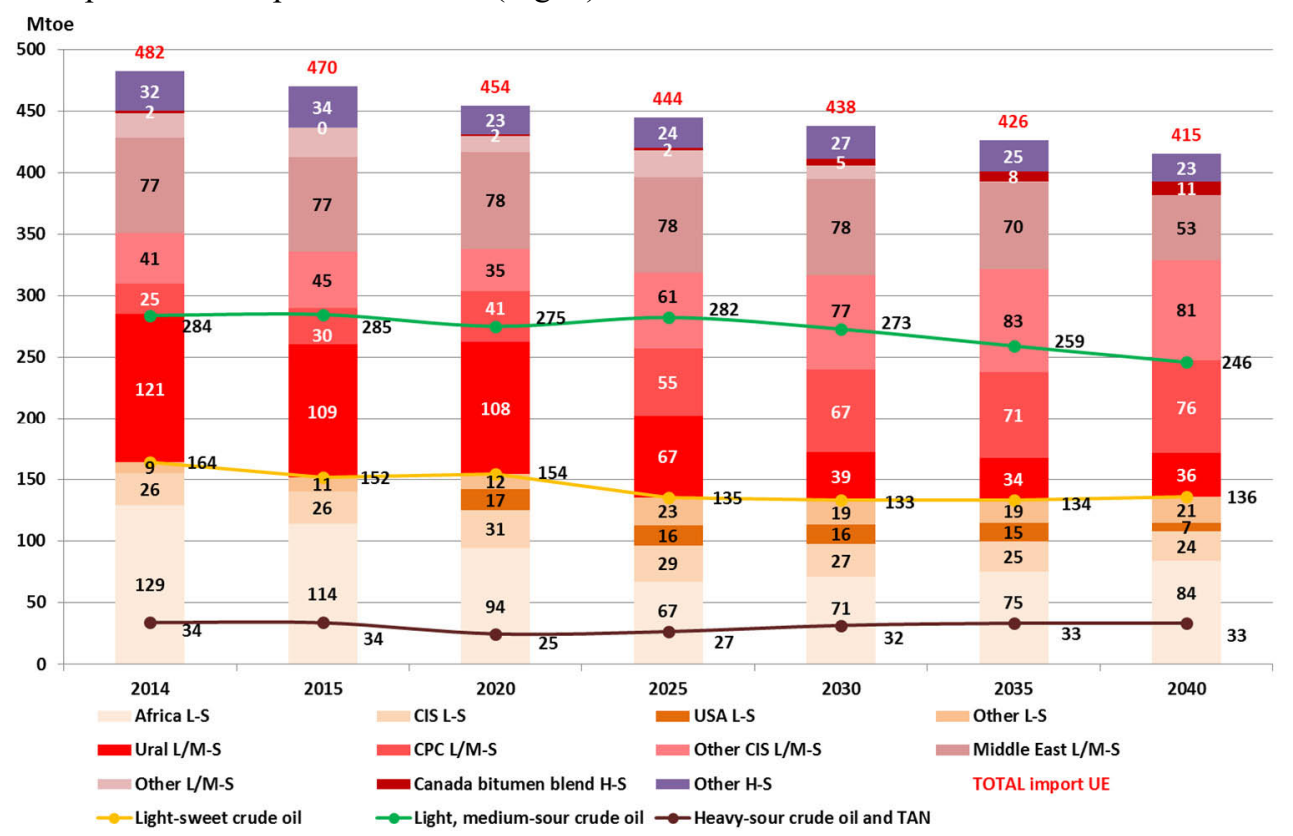

L-S light, sweet; L/S-K light/medium sour; C-K heavy/very heavy sour, TAN - „,corrosive” crude oil.

Fig. 7. The structure of the forecasted imports of crude oil to the European Union broken down by oil types [3]

\section{The structure of the planned petroleum products trade}

The European Union will continue to import petroleum products (middle distillates, jet fuel and other refined products (mainly LPG)). Meanwhile, the United States is implementing the strategy to become the exporter of these products. On the basis of the available data (Fig. 8) 
it can be concluded that, the oil shortage in Europe accounts for $20-25 \%$ of the US oversupply. Firstly, it does not mean that the United States will be able to meet the European demand. However, the US can become a very interesting supplier. This, in turn, will increase the competition in the market. Secondly, other export destinations will also be of interest to the United States.

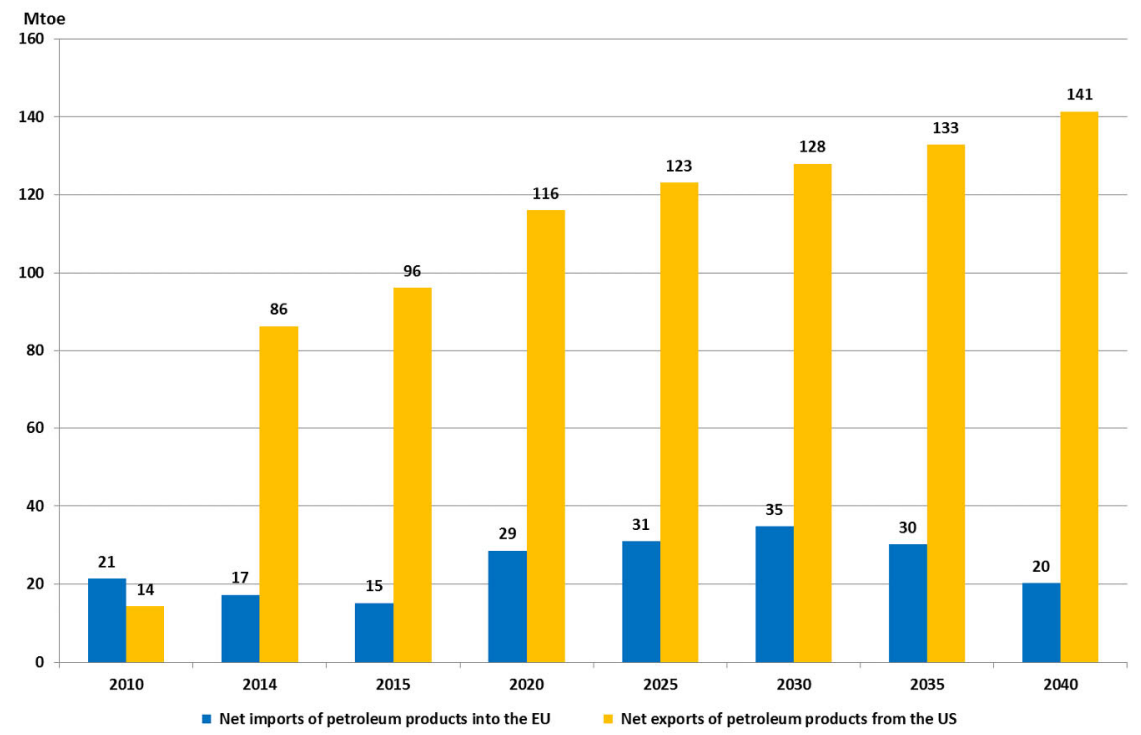

Fig. 8. Net imports of petroleum products to the EU and the net exports of petroleum products from the United States [3]

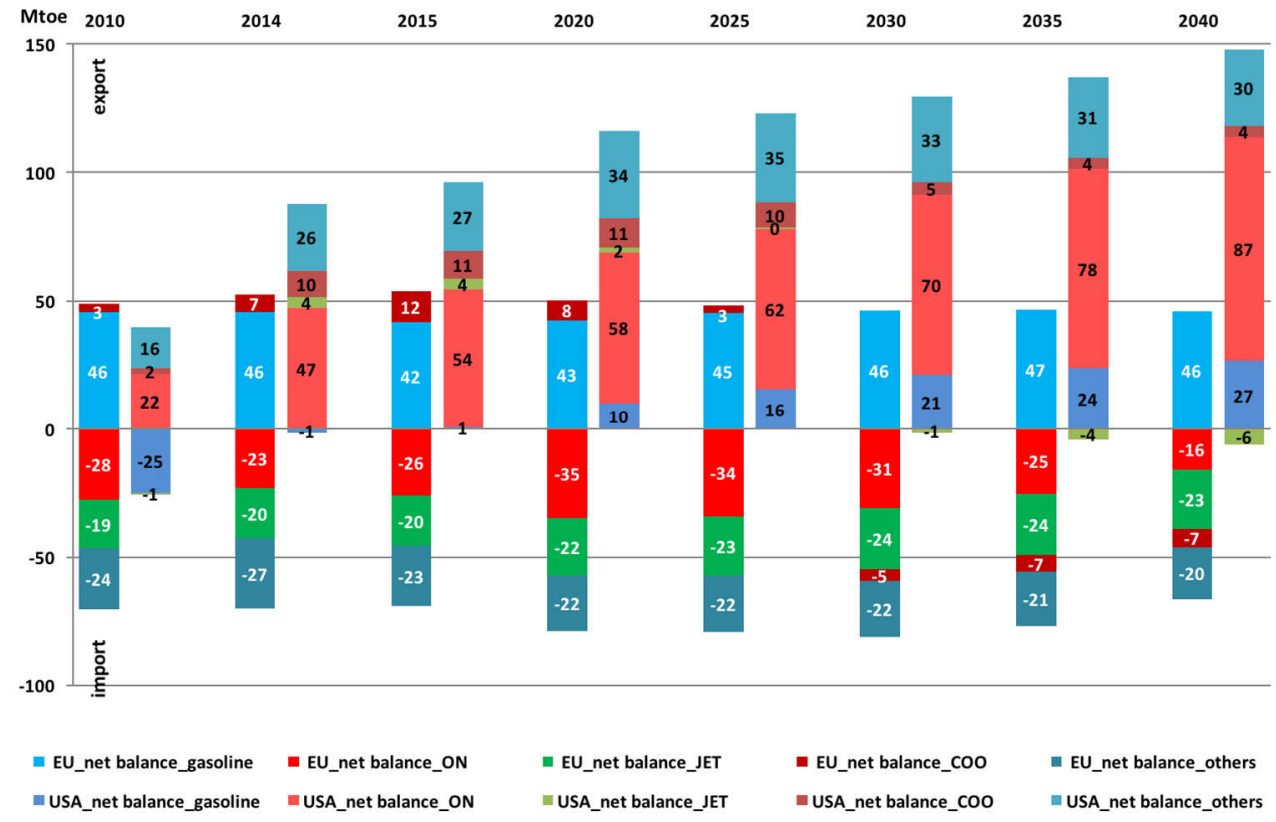

$\mathrm{ON}$ - refers to all middle distillates, JET - includes jet fuel and kerosene

Fig. 9. The net trade balance of individual petroleum products in the United States and European Union countries [3] 
When broken down by individual types of petroleum products (Fig. 9), middle distillates, mainly diesel and, to a lesser extent, LPG and kerosene, are expected to be the leading export product of the United States. In the next 10-20 years, an increase in gasoline exports is also expected.

\section{Differences in price levels, costs and logistics}

\subsection{Oil}

As mentioned before, there is a whole range of types of crude oil. Therefore, the data compiled by the Energy Studies Institute in Warsaw on North American oils and crude oil imported to Europe [1] will be used for the purpose of further analysis (to compare products with similar properties and suitability) (Fig. 10).

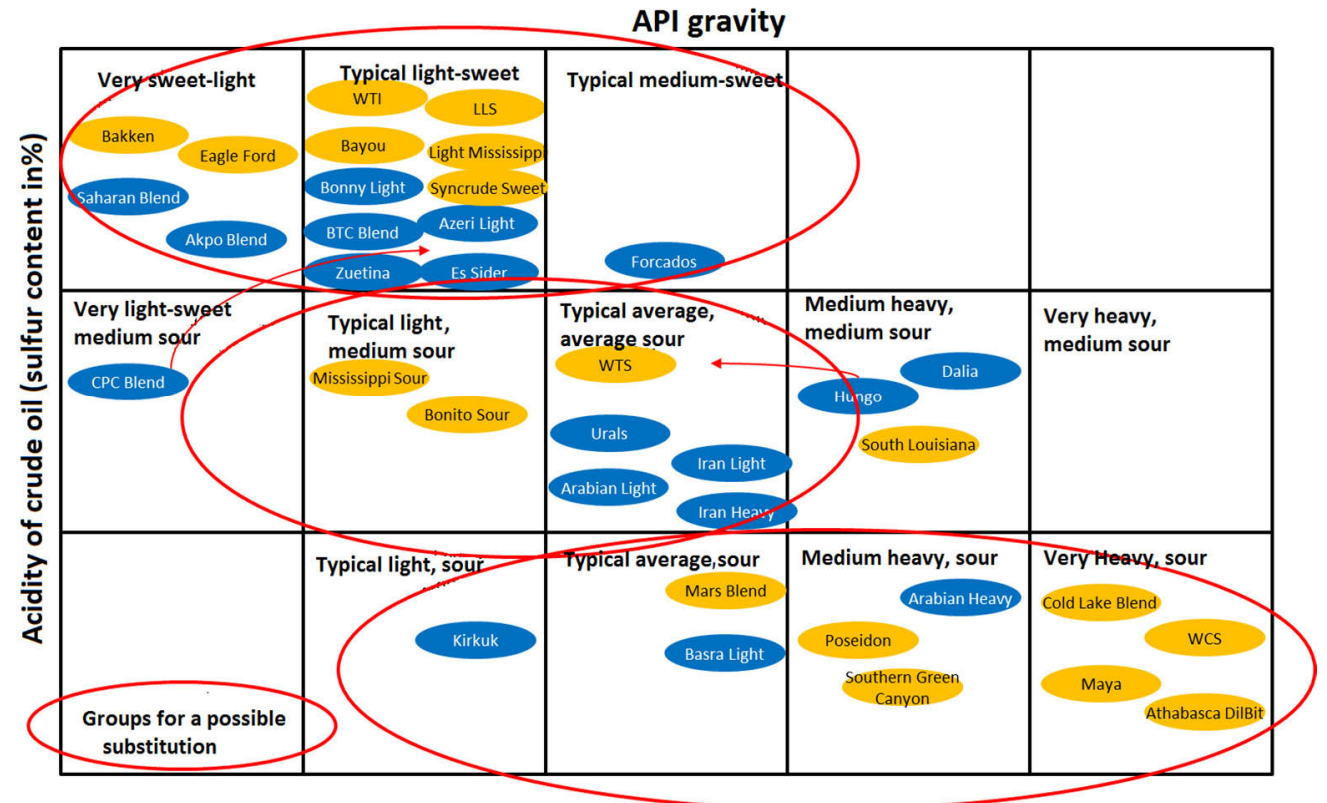

Fig. 10. The substitution matrix for individual types of crude oil used in North America and Europe [3]

It has been shown that light crude oils are the most suitable for substitution in the case of European imports. However their export potential is limited. On the other hand, the group of heavy and very sour crude oils, which could be exported, is not sought after by European refineries. The exception is the CPC Blend, which is very light (43-45 API), with sulphur content only slightly too high to consider it sweet $(0.56 \%)$, which is why it is included in the group for a possible substitution with light, sweet crude oils.

Another important point is the cost of transport from the United States (mainly the Gulf of Mexico) to the European markets (NWE, MED, or CE). CIF prices - Cost, Insurance and Freight (named port of destination) - are known for oil supplies from the Middle East, Africa or former CIS countries, while the available quota and price forecasts for US crude oils (Loco prices) are provided by the USGC (the Gulf of Mexico). Therefore, the analysis should take into account these differences.

The analysis of the results shows that US crude oils: 
- Light and sweet crude oils (Eagle Ford oil, WTI) are competitively priced and cheaper than their competitors for the entire period of the analysis (up to 2020 and 2025 for Bakken and LLS crude oil, respectively);

- Medium sour crude oils (WTS) are also attractively priced in relation to their substitutes. (up to 2025 and 2035 for Urals and Middle East crude oil, respectively);

- The analysis of medium heavy crude oils (API below $30^{\circ}$ ), heavy crude oils (API $<22^{\circ}$ ), and sour crude oils is more complicated, because only Mars Blend, Poseidon, and Southern Green Canyon are substitutes for crude oil from the Middle East. Other crude oils are considered to be much "heavier" and therefore are not of interest to European refineries. From these relations, it can be found that US crude oils are more attractively priced than crude oils from the Middle East.

To sum up, the price of imported oil should be cheaper by about 3-9 USD/bbl, while the trend should decrease to $0.5-1 \mathrm{USD} / \mathrm{bbl}$. For petrochemical companies, processing huge amounts of this raw material, a price difference of $\$ 1$ per barrel means millions of dollars in savings.

\subsection{Petroleum products}

It is clearly visible that higher (or lower) petroleum products prices are leading to a positive (or negative) net balance of trade (Fig.9). There is an oversupply of gasoline in both the United States and the EU, while the prices offered by European refineries are much more favorable.

As a consequence, the import of European products to the United States is expected. The price of jet and kerosene fuels is variable. Until 2019, the most profitable solution is to import oil from the United States, in the years 2020-2030 prices are unattractive for both parties, while after the year 2030 exports from the EU to the US seem to be the preferred option.

In the case of heavy fuel oil, changes in trade trends can be observed from the year 2030 . When it comes to kerosene, an interesting paradox occurs: While a deficit of this product in the EU is accompanied by an oversupply in the US, the analysis has shown that it is more beneficial to export kerosene to the US. Another point worth mentioning is the planned elimination of customs duties. The elimination of import tariffs will raise the potential profits of exporters. This applies to all of the discussed products (except for medium distillates).

\subsection{The forecast of the potential trade volume}

\subsubsection{Baseline scenario without changes resulting from the TTIP agreement}

According to the available data, the volume of exports of sweet crude oil from the US to the European market (Fig. 5) during the peak period (2025-2030) will remain at a level of 15-17 Mtoe/year with a downward trend to 7 Mtoe (in the year 2040). Based on the expert analysis carried out at the Energy Studies Institute in Warsaw it has been shown that the volume of oil imports from the European Union to the United States (at current import tariffs) can reach up to 700 Mtoe (2015-2040) with the highest share for gasoline $(65 \%)$, followed by heavy fuel oil $(20 \%)$, jet fuel $(12 \%)$, and kerosene $(4 \%)$. In relation to the United States, the total trade volume may reach up to 850 Mtoe (with import tariffs on middle distillates) or 2520 Mtoe if no import tariffs are imposed. Without going into details, it is clear that the elimination of trade barriers between the European Union and the United States would be 
more beneficial to US refineries Due to the higher import tariffs to the EU, the potential benefits of US exporters are higher than those of the EU exporters to the US.

\subsubsection{The potential impact of the TTIP agreement for the baseline scenario}

Firstly, a possible change in the volume of oil imports from the United States to the European Union requires more favorable prices of comparable crude oils [1]. Secondly, an increase in the volume of oil imports can take place if European crude oils will be of equal interest to US customers.

It should be noted that the Transatlantic Trade and Investment Partnership and the resulting development of trade relations between the parties (e.g. shifting of export volumes from other "preferred" markets to the European market) would allow this scenario to occur. The realization of this scenario (Fig. 11) would allow the United States to export over 100 Mtoe of oil to the European Union (about $23 \%$ of the total demand of European refineries).

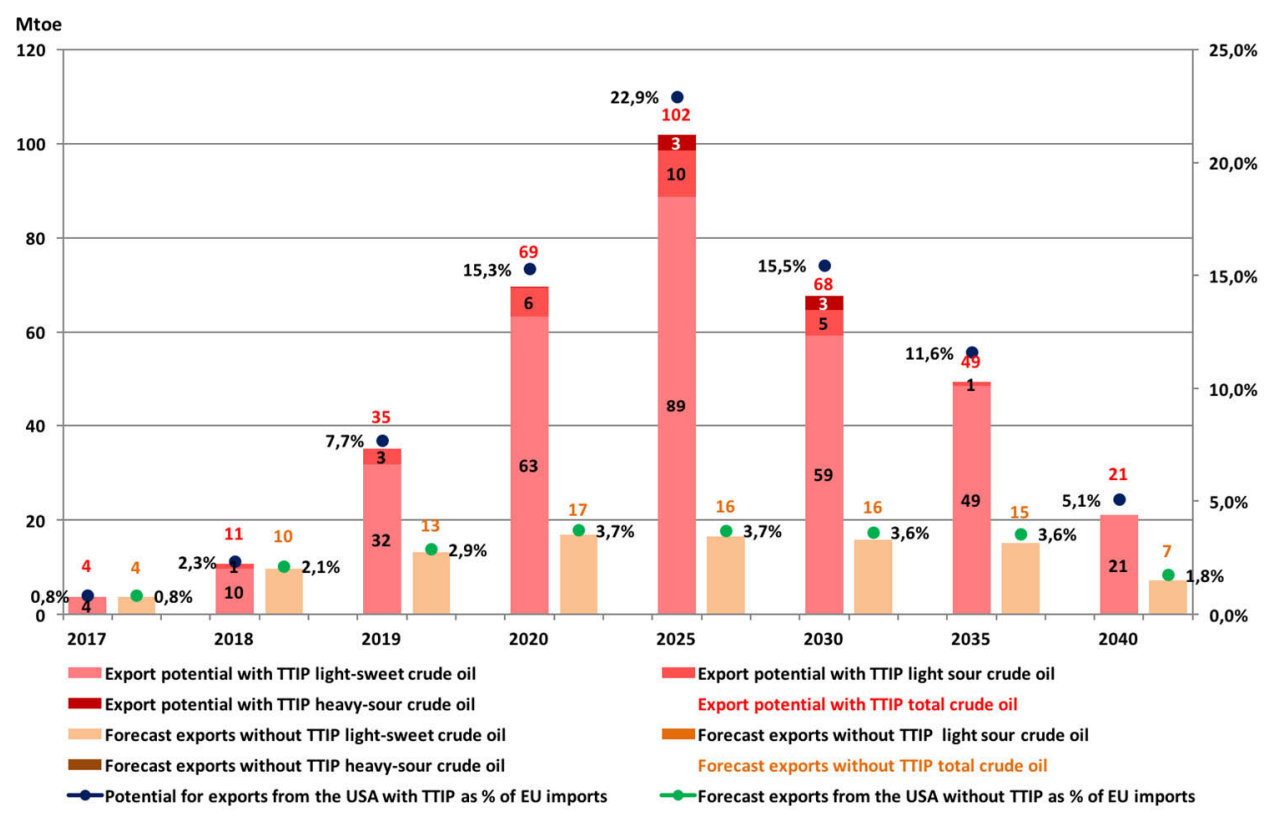

Fig. 11. Evaluation of the potential of oil exports from the United States and Canada to the European Union following the signing of the TTIP [3]

The low volume of medium sour crude oil and sour crude oil offered by the United States does not have a major impact on petrochemical plants in Poland. Sweet crude oil processed in Polish refineries in Płock and Gdańsk accounts for only about 10\% of their processing capacity [5].

In the case of petroleum products, the TTIP agreement will have a negligible impact on increasing the export volume. Despite import tariffs, light and middle distillates including LPG, gasoline, and jet fuel already guarantee the profitability of exporters $[6,7]$. The elimination of trade barriers would not increase volumes, though is expected to increase profitability (Fig. 12). It should be emphasized that the duties are much higher for goods imported to the European Union (3.5-4.7\% ad valorem) compared to the tariffs in the US (0.052-0.52 USD/bbl or $0.1-0.5 \%)$. 


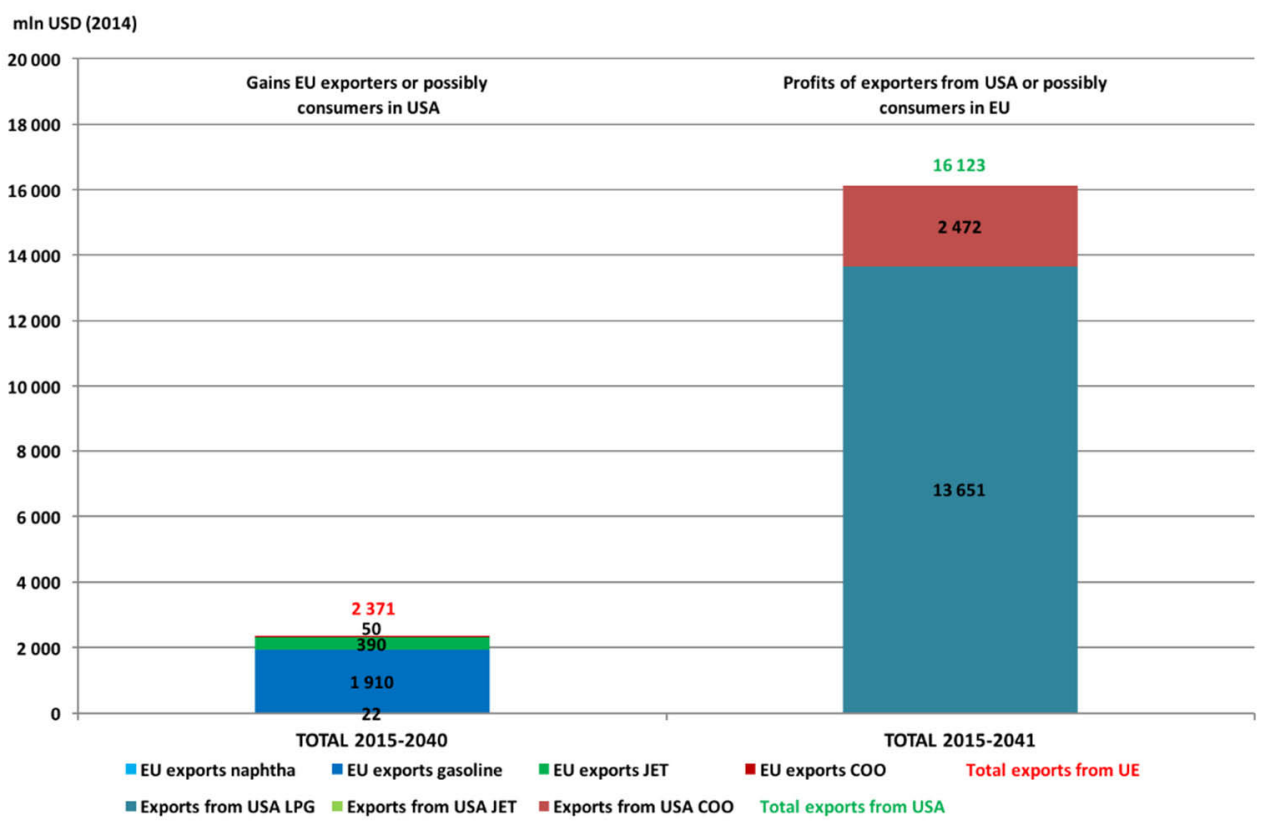

Fig. 12. The potential benefits resulting from the elimination of tariffs for exporters in the United States and the European Union [3]

\section{Summary}

The elimination of trade barriers between the European Union and the United States would be more beneficial to US refineries. Due to the higher import tariffs to the EU, the potential benefits of US exporters are higher than those of the EU exporters to the US.

The Transatlantic Trade and Investment Partnership and the resulting development of trade relations between the parties (e.g. shifting of export volumes from other "preferred" markets to the European market), would allow the United States to export over 100 Mtoe of oil to the European Union (about $23 \%$ of the total demand of European refineries).

The low volume of medium sour crude oil and sour crude oil offered by the United States does not have a major impact on petrochemical plants in Poland. Sweet crude oil processed in Polish refineries in Płock and Gdańsk accounts for only about $10 \%$ of their processing capacity.

In the case of petroleum products, the TTIP agreement will have a negligible impact on increasing the export volume.

The paper is an effect of the statutory project no. 11.11.210.217.

\section{References}

1. At a time when the article was prepared, TTIP negotiations and most of documents were confidential. TTIP text has not been published. Analysis in this article were based primarily on the analysis of documents and data selected by authors, primarily data from the European Commission - EU negotiating texts in TTIP http://trade.ec.europa.eu/doclib/press/index.cfm?id=1230 
2. BP Statistical Review of World Energy 2015

3. Costs and benefits for the Polish energy sector resulting from the planned trade agreement between the EU and the USA (TTIP) - The Energy Studies Institute in Warsaw. (unpublished material). (2015)

4. Janusz P., Kaliski M., Szurlej A., „The shale gas revolution' and changes on the LNG market. Mineral Resources Management”, vol. 31, Issue 3, pp. 5-24. (2015)

5. Krupa M., Sikora A., Sikora M., „The Yankee has struck oil” (Jankesom uderzyła ropa) (The potential Transatlantic Trade and Investment Partnership (TTIP) impact on the European and Polish chemical sectors), Przemysł Chemiczny 94/10, October 2015, DOI: 10.15199/62.2015.10.2, pp. 1641-1645 (2015)

6. Olkuski T., Sikora A., Sikora M., Szurlej A., Tora B., „Rynek gazu ziemnego w kontekście umowy TTIP" (Natural gas market in context of Transatlantic Trade and Investment Partnership), Rynek Energii 5 (126), październik 2016 http://www.cire.pl/item,137112,2,0,0,0,0,0,rynek-gazu-ziemnego-w-kontekscieumowy-ttip.html

7. Sikora A., Sikora M., Krupa M., „Zniesienie zakazu eksportu ropy naftowej ze Stanów Zjednoczonych Ameryki Północnej oraz struktura prognozowanego eksportu" (Lifting the ban on oil exports from the United States of America and the structure of projected exports), CIRE, 30.12.2015 - http://www.cire.pl/item,122786,2,0,0,0,0,0,zniesieniezakazu-eksportu-ropy-naftowej-ze-stanow-zjednoczonych-ameryki-polnocnej-orazstruktura-prognozowanego-eksportu.html (2015)

8. Sikora M., „Sikora: polska dywersyfikacja dostaw ropy naftowej” (Polish diversification of crude oil supplies), CIRE, http://www.cire.pl/item,128945,13,0,0,0,0,0,sikora-polska-dywersyfikacja-dostawropy-naftowej.html (2016)

9. Sikora A., Sikora M., Szurlej A., Cios S., Jarosz R., „Analiza kosztów i korzyści Polski i UE związanych z planowaną umową handlową między UE i USA (TTIP) podsumowanie chemia" (The potential Transatlantic Trade and Investment Partnership (TTIP) impact on the European and Polish chemical sectors), Przemysł Chemiczny, No. 5-2016, Vol. 95, May 2016, pp. 883-889, DOI: 10.15199/62.2016.5.1 (2016)

10. Sikora M., Sikora A., Szurlej A., Olkuski T., „The impact of TTIP agreement on the European Union-United States coal trade potential", International Scientific Conference on Sustainable Energy and Environment Development SEED'2016, AGH UST in Krakow, May 17th - 19th, 2016, DOI: 10.1051/e3sconf/20161000069 - http://www.e3sconferences.org/articles/e3sconf/pdf/2016/05/e3sconf_seed2016_00069.pdf

11. Sikora A., Sikora M., „Rewolucja po amerykańsku” (American revolution), Chemia przemysłowa, $3 / 2016$, str. 70

12. The World Energy Outlook 2014. IEA 2015. (2015) 